\title{
Pengukuran Beban Kerja Petugas Keamanan Untuk Memenuhi Standard Minimal Tingkat Keamanan Lingkungan
}

\author{
Arief Rahman, Anny Maryani, Astri Elmadhania \\ Jurusan Teknik Industri, , Fakultas Teknologi Industri, Institut Teknologi Sepuluh Nopember (ITS) Surabaya Jl. \\ Arif Rahman Hakim, Sukolilo, Indonesia \\ rahmanarief@gmail.com
}

\begin{abstract}
Abstrak
Keamanan lingkungan menjadi kebutuhan mendasar untuk menciptakan suasana kerja yang kondusif dan sebagai upaya untuk menjaga segala aset atau sumber daya dalam suatu organisasi. Semakin tinggi tingkat keamanan suatu lingkungan akan semakin rendah risiko kerugian akibat kehilangan aset atau bahaya yang mengancam personil. Petugas kemanan dalam suatu lingkungan kerja menjadi salah satu tumpuan untuk melaksanakan fungsi-fungsi pengamanan dan penyelamatan. Secara rutin dan berlanjut, petugas keamanan melakukan kegiatan monitoring terhadap aset-aset internal dan pemeriksaan lalu lintas kendaraan dan orang yang masuk serta keluar lingkungan. Perhitungan jumlah petugas keamanan perlu mempertimbangkan target tingkat keamanan lingkungan, cakupan luas area pengamanan, volume dan frekuensi kendaraan/orang/aset/perangkat yang harus diamati atau diperiksa. Penentuan jumlah petugas keamanan yang diperlukan untuk memenuhi standar minimal keamanan. Simulasi proses pemeriksaaan surat kendaraan pada pos keamanan dikembangkan dalam penelitian ini untuk mengukur beban kerja petugas keamanan. Jumlah petugas keamanan yang dipertimbangkan dalam simulasi adalah 1 petugas, 2 petugas dan 3 petugas. Sedangkan tingkat pengamanan yang diperhitungkan adalah pada tingkat 100\%, 90\%, 80\%, $70 \%$, dan $50 \%$. Berdasarkan pola data kedatangan kendaraan dan pola waktu siklus pemeriksaan surat kendaraan, penelitian ini dapat menggambarkan beban kerja petugas keamanan terhadap tingkat keamanan yang ingin diterapkan. Untuk menerapkan tingkat pengamanan maksimal yaitu $100 \%$, diperlukan 3 orang petugas keamanan pada tiap pos. Dengan jumlah petugas keamanan sebanyak 2 orang, kondisi beban kerja normal dapat dicapai dengan tingkat keamanan $90 \%$. Namun dengan 1 orang petugas keamanan, tingkat keamanan yang dapat dicapai akan kurang dari 50\%.
\end{abstract}

Kata kunci: Beban Kerja, Petugas Keamanan, Tingkat Keamanan, Studi Waktu Kerja, Simulasi.

\section{PENDAHULUAN}

Keamanan kampus yang aman merupakan kondisi yang harus diciptakan dalam upaya untuk menjaga segala aset atau sumber daya dalam suatu organisasi. Semakin tinggi tingkat keamanan suatu lingkungan akan semakin rendah risiko kerugian akibat kehilangan aset atau bahaya yang mengancam personil. Petugas kemanan dalam suatu lingkungan kerja menjadi salah satu tumpuan untuk melaksanakan fungsi-fungsi pengamanan dan penyelamatan. Secara rutin dan berlanjut, petugas keamanan melakukan kegiatan monitoring terhadap aset-aset internal dan pemeriksaan lalu lintas kendaraan dan orang yang masuk serta keluar lingkungan.

Karakteristik kerja petugas kemanan dikategorikan sebagai perkerjaan yang rutin non-repetitif dengan siklus yang jelas. Dalam kondisi normal atau aman, melakukan pengawasan terhadap kendaraan, orang, aset/barang, atau perangkat kerja merupakan aktivitas pokok yang dominan dilakukan oleh petugas keamanan. Aktivitas pengawasan atau aktivitas patroli cukup sulit untuk dinilai apakah merupakan aktivitas yang produktif atau tidak. Berdasarkan kondisi tersebut maka penentuan jumlah petugas keamanan menjadi menarik untuk dibahas. Perhitungan jumlah petugas keamanan perlu mempertimbangkan target tingkat keamanan lingkungan, cakupan luas area pengamanan, volume dan frekuensi kendaraan/orang/aset/perangkat yang harus diamati atau diperiksa. Penentuan jumlah petugas keamanan yang diperlukan untuk memenuhi standar minimal keamanan.

Produktivitas pegawai dapat diukur dari aktivitas yang memberikan nilai tambah (value added) pada pengamanan lingkungan kampus. Melakukan pengamatan atau pengawasan terhadap lalu lintas kendaraan atau orang pada pintu keluar/masuk merupakan dalah satu aktivitas yang memberikan nilai tambah. Sebaliknya, aktivitas berbicara dengan sesama petugas yang meniadakan fungsi pengawasan dapat dikategorikan sebagai aktivitas yang tidak memberikan nilai tambah (nonvalue added). Daftar aktivitas dari petugas keamanan kampus yang dijadikan acuan dalam penelitian ini dapat dilihat pada Gambar 2. Pengamatan aktivitas petugas keamanan di kampus ITS dengan pendekatan sampling telah dilakukan selama 2 minggu atau 14 hari (termasuk hari libur). Hasil sampling terhadap aktivitas petugas keamanan dapat dilihat pada gambar 1 dibawah ini. \%value added tertinggi dapat dijumpai pada Pos 2 sebesar 52\% dan Pos 1B sebesar 48\% dan menunjukkan masih terdapat peluang yang cukup tinggi untuk meningkatkan \%value added. Sedangkan produktivitas pos lainnya masih 
rendah dan kondisi ini menunjukkan masih tingginya peluang untuk meningkatkan fungsi pengamanan pada pos-pos jaga di kampus ITS.

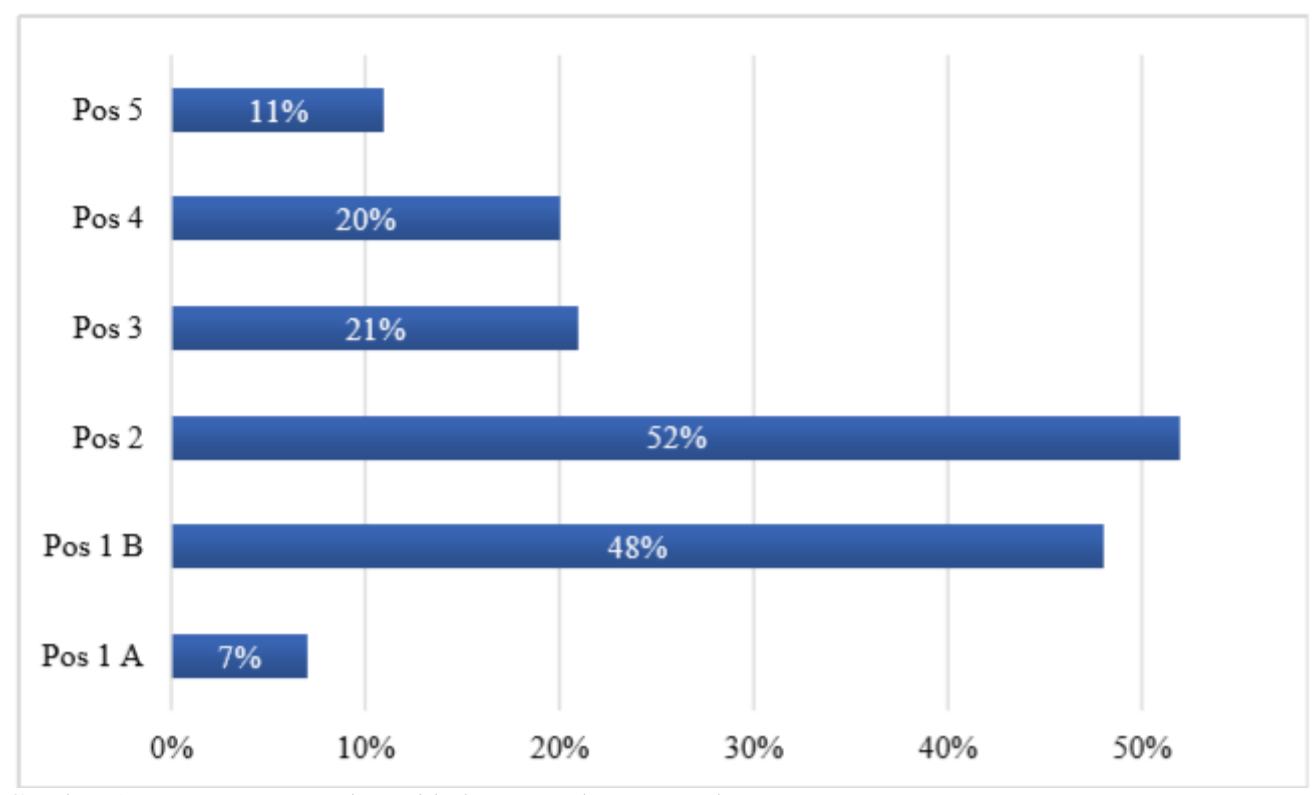

Gambar 1. Prosentase \% value added petugas keamanan kampus

Hasil yang lebih terperinci dari hasil sampling produktivitas satuan keamanan kampus menunjukkan bahwa prosentase aktivitas non-value added masih sangat tinggi. Gambar 2 menampilkan proporsi aktivitas dari seluruh 5 pos amatan. Ketidakhadiran petugas keamanan menempati proporsi paling tinggi yaitu 38.8\% sebagai aktivitas non-value added. Aktivitas menunggu sambil berbicara, menunggu diam saja, dan menunggu sambil menggunakan handphone mencapai proporsi $12 \%$, $11,2 \%$ dan $10.4 \%$ yang juga diklasifikasikan sebagai aktivitas non-value added. Sehingga dengan mempertimbangkan 4 aktivitas tersebut saja telah mencapai prosentase sebesar $72.5 \%$.

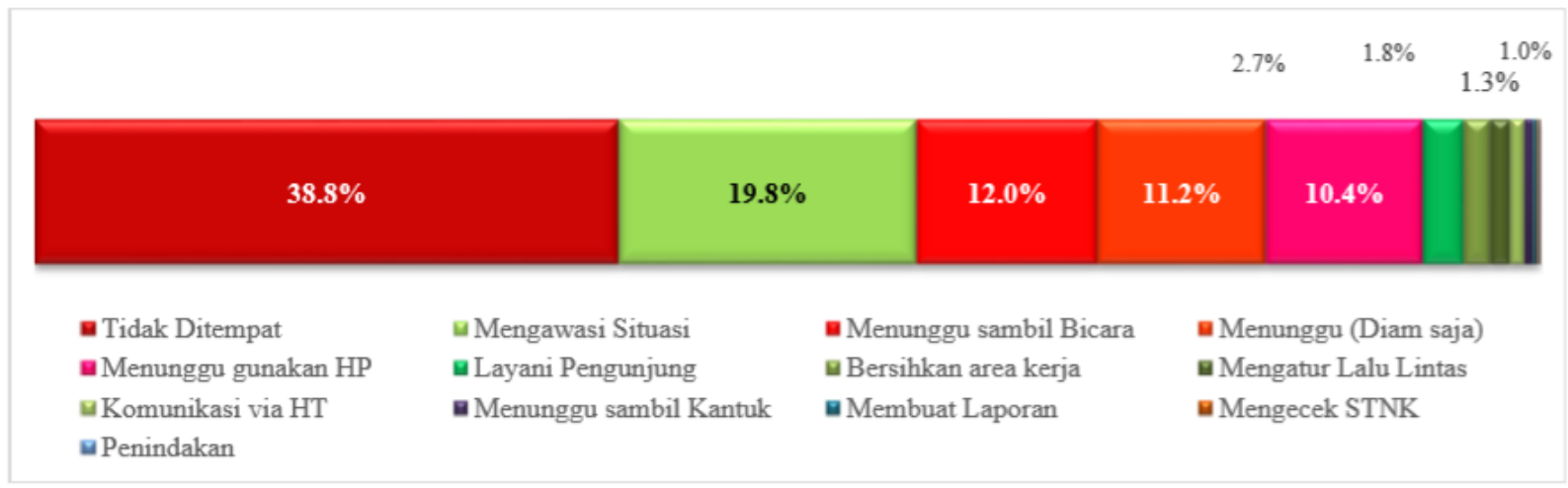

Gambar 2. Prosentase rincian aktivitas kerja pada semua pos amatan

Berdasarkan hasil sampling produktivitas petugas keamanan kampus tersebut, menunjukkan peluang besar untuk meningkatkan produktivitas petugas keamanan kampus. Upaya peningkatan produktivitas petugas keamanan kampus dapat dilakukan dengan pengaturan beban kerja yang dapat dikaitkan dengan upaya peningkatan tingkat keamanan dalam lingkungan kampus. Dengan sistem pengamanan yang masih sangat tergantung pada kinerja petugas keamanan, maka target tingkat pengamanan yg paling tinggi (setiap orang/kendaraan/barang diperiksa 100\%) akan berimbas pada beban kerja yang semakin tinggi. Semakin tinggi tingkat pengamanan juga akan berdampak pada tingkat kenyamanan, misal akan semakin lamanya proses pemeriksaan orang/kendaraan/barang. Sehingga penelitian ini akan mencari kondisi optimal yang dapat dicapai agar produktivitas petugas keamanan meningkat dan tingkat keamanan akan semakin tinggi dengan simulasi beban kerja.

\section{BEBAN KERJA}

Beban kerja dapat didefinisikan sebagai suatu proses analisis terhadap waktu yang digunakan oleh seseorang atau sekelompok orang dalam menyelesaikan tugas-tugas suatu pekerjaan (jabatan) atau kelompok jabatan (unit kerja) yang dilakukan dalam keadaan normal kurnia. Sedangkan menurut Peraturan Menteri Dalam Negeri No.12/2008, beban kerja adalah besaran pekerjaan yang harus ditanggung oleh suatu jabatan atau unit organisasi dan merupakan hasil kali antara volume kerja dan norma waktu. Sehingga, dapat disimpulkan bahwa beban kerja merupakan sebuah proses yang dilakukan oleh seseorang dalam menyelesaikan tugas-tugas pekerjaan atau kelompok jabatan dalam jangka waktu yang sudah ditentukan dan dilaksanakan dalam kondisi normal [1]. 
Lebih lanjut, menurut [2], beban kerja adalah : a) jumlah pekerjaan atau waktu bekerja yang diharapkan dari atau diberikan kepada pekerja dan b) total jumlah pekerjaan yang harus diselesaikan oleh suatu departemen atau kelompok pekerja dalam suatu periode waktu tertentu. Dengan adanya definisi ini, Lysaght, et al. membagi definisi beban kerja dalam tiga kategori besar, yakni :

1. Banyaknya pekerjaan dan hal-hal yang harus dilakukan.

2. Waktu maupun aspek-aspek tertentu dari waktu yang harus diperhatikan oleh pekerja.

3. Pengalaman psikologis subyektif yang dialami oleh seorang pekerja.

Berdasarkan definisi mengenai beban kerja menurut Lysaght, et al. di atas, dapat ditarik kesimpulan bahwa beban kerja menunjukkan seberapa besar kapasitas individu pekerja dibutuhkan dalam menyelesaikan tugas yang diberikan kepadanya, yang dapat diindikasikan dari :

1. Jumlah pekerjaan yang harus dilakukan.

2. Waktu atau batasan waktu yang dimiliki oleh pekerja dalam menyelesaikan tugasnya.

3. Pandangan subyektif individu tersebut sendiri mengenai pekerjaan yang diberikan kepadanya.

Pemberian beban kerja untuk tiap-tiap operator harus disesuaikan dengan kemampuan yang dimiliki oleh operator atau karyawan tersebut agar tidak terjadi kegagalan dalam menyelesaikan suatu pekerjaan [3]. Beban kerja yang diberikan kepada karyawan dapat dibagi menjadi 3 (tiga) kondisi. Pertama, beban kerja sesuai standar, kedua, beban kerja terlalu tinggi (overload), dan ketiga, beban kerja terlalu rendah (underload). Pemberian beban kerja yang overload dapat menimbulkan kelelahan, baik fisik maupun mental, dan reaksi-reaksi emosional, seperti sakit kepala, gangguan pencernaan, dan mudah marah. Sedangkan pemberian beban kerja yang underload dapat menimbulkan kebosanan dan rasa monoton karena adanya pengurangan gerak pada pekerjaan yang dilakukan. Apabila pegawai mengalami kebosanan dalam menjalankan pekerjaan rutinnya karena pekerjaan yang diberikan kepadanya terlalu sedikit, maka hal ini dapat mengakibatkan kurangnya perhatian pada tanda-tanda stress yang berkaitan dengan tingkat beban kerja [4]. Beban kerja yang terlalu tinggi maupun rendah dapat mengakibatkan inefisiensi kerja. Beban kerja yang terlalu rendah mengindikasikan terjadinya kelebihan tenaga kerja. Kelebihan ini menyebabkan organisasi harus menggaji jumlah karyawan lebih banyak dengan produktivitas yang sama, sehingga menyebabkan terjadinya inefisiensi biaya. Sedangkan beban kerja yang terlalu tinggi mengindikasikan terjadinya kekurangan tenaga kerja. Hal ini berakibat pada kelelahan fisik maupun psikologis bagi karyawan yang pada akhirnya menyebabkan karyawan tidak produktif karena terlalu lelah [5]. Oleh karena itu, penting untuk dilakukan pengukuran atau analisis beban kerja, salah satunya untuk manajemen dan kesehatan karyawan.

\section{METODE PENELITIAN}

Pelaksanaan penelitian dilakukan melalui beberapa tahapan sebagai berikut :

- Sampling produktivitas petugas keamanan Pengamatan aktivitas petugas keamanan di 6 pos keamanan yaitu pintu keluar kendaraan bermotor telah dilakukan selama 2 minggu (14 hari). Pengamatan menggunakan metode sampling yang dimulai pada pukul 06.00 sampai dengan pukul 21.00. Observer melakukan pengamatan berdasarkan tabel sampling yang memuat daftar aktivitas-aktiivtas. Aktivitas yang diamati meliputi aktivitas value added seperti melakukan pengawasan, dan non-value added seperti menunggu sambil mengoperasikan handphone.

- Perhitungan volume kendaraan Pengamatan dan perhitungan volume kendaraan yang keluar melalui pos pengamanan dilaksanakan untuk mendapatkan pola waktu antar kedatangan dari tiap kendaraan (sepeda motor). Dengan menggunakan aplikasi VAnalyzer, waktu-waktu kedatangan dari tiap kendaraan dapat direkam dan dicatat waktu rincinya. Pengamatan dilakukan pada waktu-waktu tertentu yang mewakili pola kedatangan yang padat, normal, dan sepi. Gambar 3 dibawah ini merupakan salah satu pola kedatangan kendaraan pada salah satu pos pengamanan

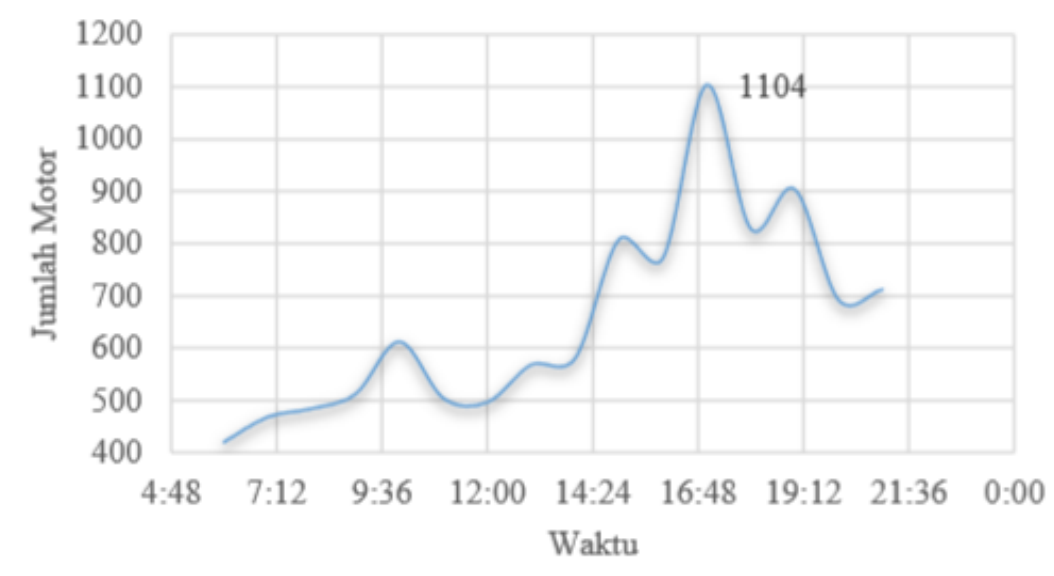

Gambar 3. pola kedatangan kendaraan bermotor pada salah satu pos keamanan. 
- Simulasi proses pemeriksaan kendaraan pada pos keamanan Model simulasi telah dibangun untuk menampilkan proses pemeriksaan STNK di pos keamanan. Proses pemeriksaan STNK atau surat kendaraan menjadi proses penting untuk disimulasikan karena menyangkut proses seleksi kendaraan yang keluar dari lingkungan ITS. Skenario pemeriksaan keseluruhan terhadap kendaraan yang keluar merupakan gambaran penerapan tingkat keamanan $100 \%$. Dengan simulasi dapat digambarkan beban kerja atau utilitas dari petugas keamanan yang melakukan proses pemeriksaan. Simulasi pada proses pemeriksaan menggunakan software ARENA.

\section{HASIL DAN PEMBAHASAN}

Simulasi proses pemeriksaan kendaraan bermotor (sepeda motor) pada setiap pintu keluar kampus merupakan model utama yang dihasilkan dalam penelitian ini. Masih rendahnya beban kerja petugas keamanan kampus dan sangat jarangnya proses pemeriksaan surat kendaraan sebagai proses seleksi pengamanan obyek yang keluar dari kampus merupakan persoalan yang memerlukan penerapan skenario-skenario penerapan kebijakan keamanan melalui simulasi. Untuk mencapai tingkat pengamanan yang paling baik yaitu tingkat pengamanan $100 \%$ maka seluruh obyek atau kendaraan yang keluar harus diperiksa. Bila pemeriksaan dilakukan secara keseluruhan maka terdapat kemungkinan beban kerja petugas keamanan akan sangat tinggi.

Hasil perhitungan volume kendaraan bermotor yang keluar di posko pengamanan kampus digunakan untuk menentukan pola distribusi kedatangan kendaraan. Dengan menggunakan fitur input analyzer dalam software ARENA, pola distribusi kedatangan kendaraan dapat dihasilkan seperti grafik pada Gambar 4 dibawah ini. Pola kedatangan kendaraan pada pos pengamanan umumnya mendekati distribusi exponential. Selain menentukan distribusi waktu antar kedatangan kendaraan juga ditentukan distribusi yang sesuai untuk waktu siklus aktivitas pemeriksaan surat kendaraan atau STNK.

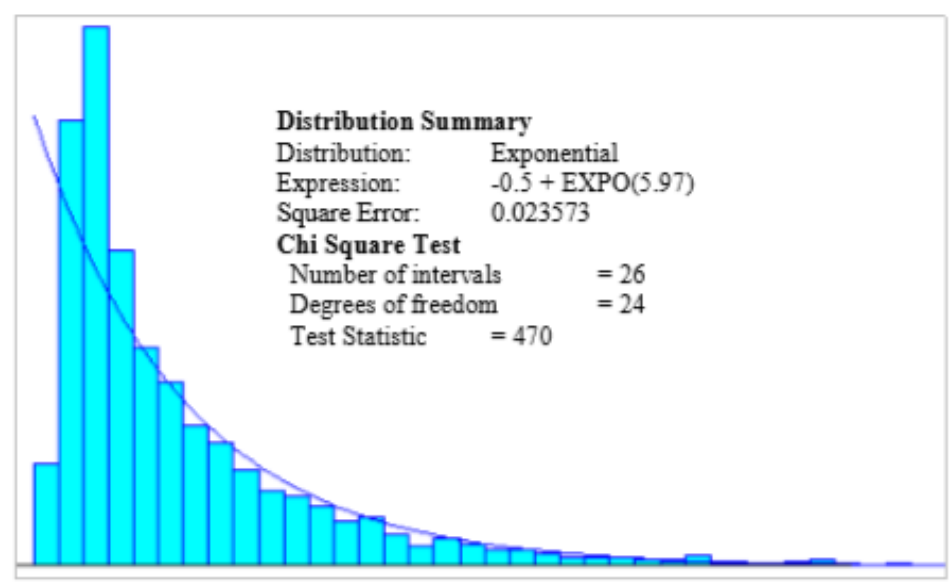

Gambar 4. Pola data waktu antar kedatangan kendaraan pada pos keamanan

Model simulasi diskrit menggunakan ARENA telah dikembangkan untuk menggambarkan proses pemeriksaan surat kendaraan. Proses diawali dengan kedatangan kendaraan bermotor yang akan keluar kampus melalui pos keamanaan.Pada tahap ini akan dibangkitkan waktu antar kedatangan tiap kendaraan berdasarkan distribusi data yang telah ditentukan. Selanjutnya kendaraan akan memasuki jalur antrian pemeriksaan pada pos keamanan. Terdapat petugas keamanan yang akan melakukan pemeriksaan. Jumlah petugas keamanan merupakan variabel dalam simulasi yang akan dievaluasi jumlahnya untuk mencapai beban kerja yang normal. Bila kendaraan harus diperiksa oleh petugas maka akan digenerate waktu siklus pemeriksaan surat kendaraan mengikuti distribusi yang telah ditentukan. Untuk tingkat keamanan yang di set kurang dari $100 \%$, maka terdapat kemungkinan kendaraan melewati pos keamanan tanpa pemeriksaan surat kendaraan dan langsung keluar lingkungan kampus. Gambar 5 menggambarkan block diagram proses pemeriksaaan surat kendaraan.

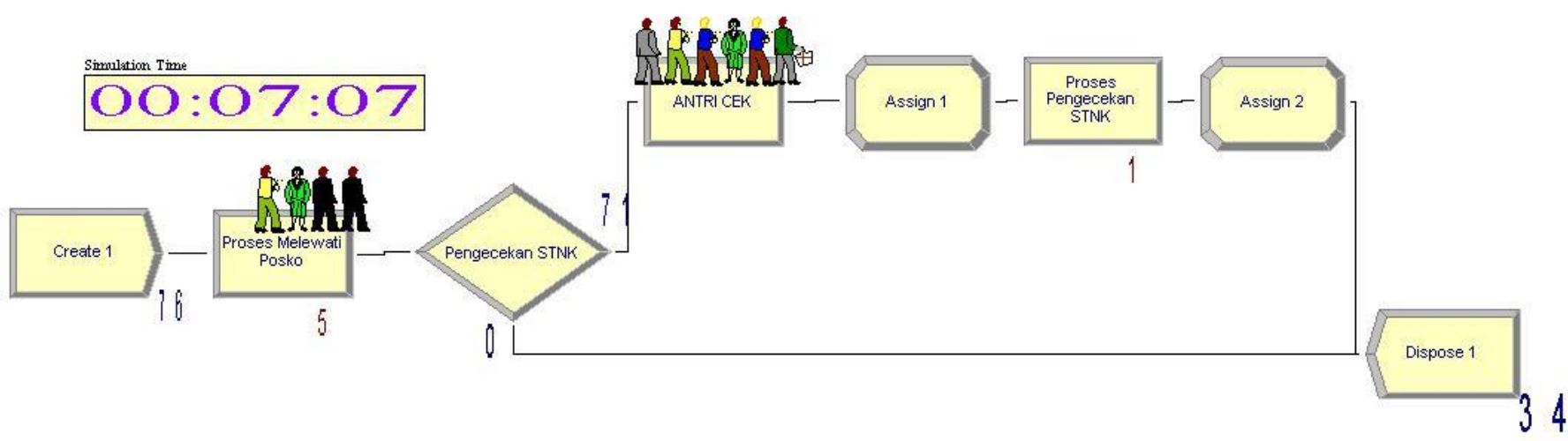

Gambar 5. Block diagram dari proses antrian di pos keamanan 
Skenario simulasi mempertimbangkan jumlah petugas keamanan yang bertugas memeriksa surat kendaraan dan tingkat pengamanan yang diterapkan. Jumlah petugas keamanan yang dipertimbangkan adalah 1 petugas, 2 petugas, dan 3 petugas. Tingkat pengamanan mempertimbangkan skenario tingkat pengamanan 100\%, 90\%, 80\%, 70\%,60\%, dan 50\%. Untuk tingkat pengamatan $50 \%$ memberikan peluang sebuah kendaraan untuk diperiksa sebesar 0.5 da sebaliknya. Lama waktu menunggu dalam proses atrian tidak dibatasi, namun dalam hasil simulasi untuk skenario diatas, lama waktu mengantri tidak akan melebihi 60 detik. Lama waktu mengantri akan mempengaruhi tingkat kenyamanan yang masih dapat diterima oleh pengendara. Simulasi dijalankan sesuai dengan durasi kerja dalam satu shift jaga yaitu mulai 8 jam simulasi.

Hasil simulasi proses pemeriksaan surat kendaraan pada pos keamanan dengan melibatkan 1 orang petugas keamanan menunjukkan bahwa beban kerja petugas keamanan diatas $95 \%$ pada semua tingkat pengamanan yang diterapkan. Beban kerja diatas $95 \%$ menunjukkan beban yang berlebih dan tidak memungkinkan untuk diterapkan. Pada penerapan skeario simulasi dengan menugaskan 2 petugas keamanan menunjukkan beban kerja yang masih tinggi untuk penerapan tingkat pengamanan $100 \%$. Namun beban kerja akan semakin menurun untuk 2 orang petugas keamanan dalam penerapan tingkat pengamanan dibawah atau sama dengan $90 \%$. Pada penerapan simulasi yang melibatkan 3 orang petugas keamanan pada tiap pos pengamanan, hasil simulasi menunjukkan beban kerja yang masih normal pada penerapan tingkat pengamanan $100 \%$. Beban kerja akan semakin menurun pada komposisi 3 orang petugas keamanan pada tingkat pengamanan yang lebih rendah dari $100 \%$. Gambar 6 dibawah ini menunjukkan pola beban kerja petugas keamanan dengan tingkat keamanan tertentu.

Upaya peningkatan produktivitas petugas keamanan yang masih rendah dapat dilakukan dengan memberikan beban tugas pemeriksaan surat kendaraan secara manual. Pemeriksaan manual surat kendaraan saat ini masih sangat jarang diterapkan oleh petugas keamanan kampus di ITS. Sehingga prosedur pemeriksaan surat kendaraan dapat diterapkan dengan prosedur tertentu.

Hasil simulasi menunjukkan tingkat keamanan yang maksimal yaitu 100\% akan menimbulkan konsekuensi jumlah petugas keamanan sebanyak 3 orang. Bila setiap pos dialokasikan 3 petugas keamanan maka untuk pengamanan lingkungan kampus ITS diperlukan 18 orang. Jumlah tersebut bukan merupakan komposisi yang efisien dan namun dapat memberikan peningkatan keamanan yang cukup significant.

Penugasan 1 orang petugas keamanan pada pos keamanan juga tidak dapat mencapai tingkat pengamanan sebesar $50 \%$ karena pada kondisi pengamanan tersebut beban petugas keamanan masih diatas $95 \%$ atau tinggi. Sehingga kompisisi 2 petugas keamanan pada sebuah pos keamanan merupakan kondisi yang optimal yaitu peluang untuk mencapai tingkat kemanan sampai $90 \%$ dengan beban kerja yang masih normal. Tingkat keamanan 90\% hanya memberikan sedikit sekali peluang lolos pemeriksaan untuk sebuah obyek atau kendaraan bermotor tanpa melalui proses pemeriksaan atau seleksi.

Penerapan teknologi deteksi benda secara otomatis seperti RFID atau NFC merupakan salah satu alternatif pilihan untuk meningkatkan pengamanan kampus. Investasi perangkat sistem deteksi perlu dihitung untuk memastikan efektivitas penerapan teknologi tersebut. Dengan penerapan sistem deteksi otomatis, tingkat keamanan 100\% sanga mungkin diterapkan dan terdapat peluang untuk mengalokasikan tugas petugas keamanan untuk menjalankan fungsi kerja lainnya. 


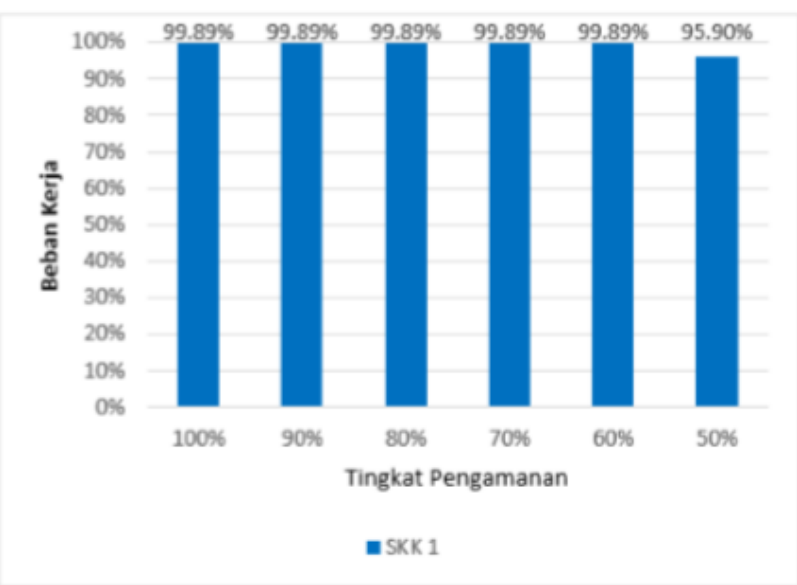

(a) 1 petugas keamanan

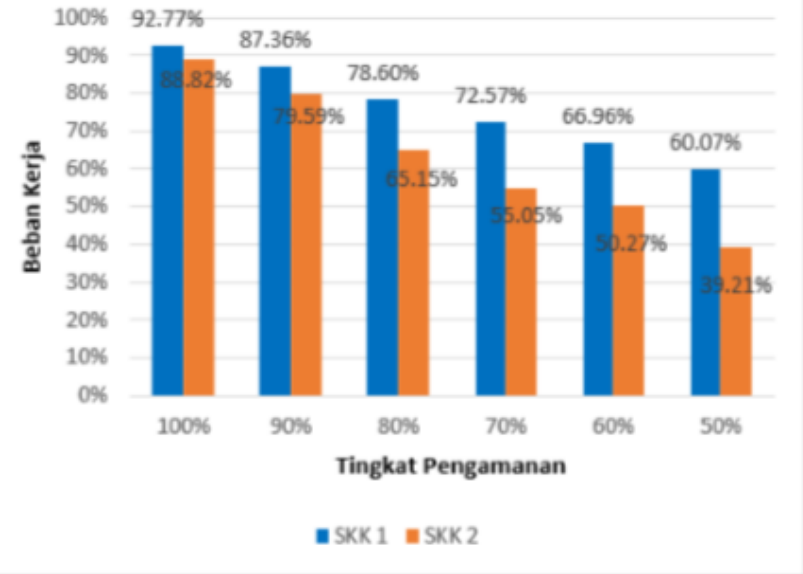

(b) 2 petugas keamanan

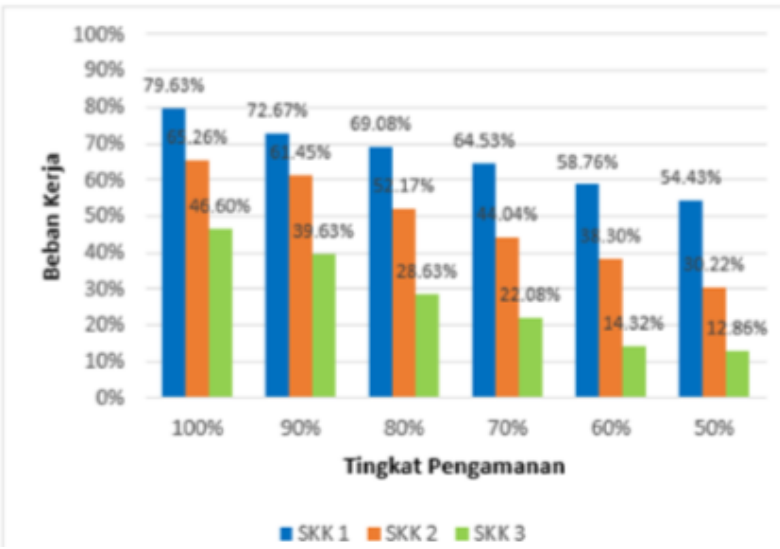

Gambar 6. Pola beban kerja petugas keamanan untuk beberapa skenario tingkat pengamanan

\section{KESIMPULAN}

Dari hasil simulasi yang diterapkan untuk beberapa skenario dapat disimpulkan sebagai berikut: a. Beban kerja petugas keamanan akan meningkat secara linear dengan peningkatan target keamanan. b. Beban kerja pada proses pemeriksaan surat kendaraan pada pos keamanan dipengaruhi oleh pola waktu antar kedatangan kendaraan di pos keamanan. c. Tingkat pengamanan maksimal dapat diterapkan dengan beban normal untuk penugasan 3 orang petugas keamanan. Penugasan 2 orang dapat mencapai tingkat keamanan mendekati $90 \%$. d. Penugasan 1 orang petugas keamanan hanya dapat mencapai tingkat pengamanan dibawah $50 \%$.

\section{DAFTAR PUSTAKA}

[1] I. Y. ANDINI, "Penentuan Kebutuhan Jumlah Tenaga Kerja Alihdaya di Terminal BBM PT. Pertamina (Persero) Marketing Operation Region VI Balikpapan,” Institut Teknologi Sepuluh Nopember, 2014.

[2] A. O. LYSAGHT, R. J., HILL, S. G., DAN DICK, Operator Workload: Comprehensive Review and Evaluation of Operator Workload Methodologies. Maryland: Analytics, Inc., 1989.

[3] S. MILLER, Workload Measures. Iowa: University of Iowa, 2001.

[4] A. MANUABA, "Ergonomi, Kesehatan, dan Keselamatan Kerja. Editor : Sritomo Wignjosoebroto dan Stefanus Eko Wiranto.," in Proceeding Seminar Nasional Ergonomi, 2000.

[5] W. NOVERA, "Analisis Beban Kerja dan Kebutuhan Karyawan Bagian Administrasi Akademik dan Kemahasiswaan (Studi Kasus : Unit Tata Usaha Departemen pada Institut Pertanian Bogor),” Institut Pertanian Bogor, 2010. 